Original citation: Madianou, M. (2016) 'Polymedia communication among transnational families: what are the long-term consequences for migration?' In Palenga, E. and M. Kilkey (eds) Family Life in an Age of Migration and Mobility: Global Perspectives through the Life Course, pp. 71-93. London: Palgrave.

Polymedia communication among transnational families: what are the long-term consequences for migration?

Mirca Madianou, Goldsmiths - University of London (․m.madianou@gold.ac.uk)

Abstract: This chapter investigates the cumulative consequences of new communication technologies for the phenomenon of migration. Drawing on a seven year long comparative and multi-sited ethnography of long-distance communication within Filipino transnational families I demonstrate that the recent convergence in new communication technologies has profound consequences not just for the migrants and their left-behind families but for the phenomenon of migration as a whole. Although new media cannot solve the fundamentally social problems of family separation, they are increasingly used as justifications for key decisions relating to migration or settlement in the host country. The chapter brings together research with migrants and institutional actors and shows that transnational communication through new media has become implicated in making female migration more socially acceptable while ultimately influencing patterns of migration.

Technologically mediated communication remains a relatively unexplored aspect of transnational family life. Although new research has recently emerged, that it took so long for this issue to be placed on the agenda of migration research is surprising given the dependency of transnational families on communication technologies, especially in conditions of prolonged separation. This chapter extends 
Original citation: Madianou, M. (2016) 'Polymedia communication among transnational families: what are the long-term consequences for migration?' In Palenga, E. and M. Kilkey (eds) Family Life in an Age of Migration and Mobility: Global Perspectives through the Life Course, pp. 71-93. London: Palgrave.

recent work on communication technologies within transnational families by exploring the cumulative consequences of mediated communication for the phenomenon of migration. Now that migrants and their families can be in daily contact achieving a sense of 'ambient co-presence' (Madianou, in press) what are the implications for the relationships and processes of migration more broadly? Drawing on a long-term ethnography (2007-2015) of transnational communication between UK-based migrant women and their left-behind children in the Philippines, I argue that new media are more than channels for personal communication. Communication technologies have significant consequences which affect the whole process of migration, by providing justifications for decisions relating to migration and return. The increasing taken-for-grantedness of transnational communication made possible because of the availability and affordability of new media emerges as an important catalyst for the transformation of patterns of migration and migratory experiences.

The Philippines, one of the most intensely migrant societies, has come to exemplify the phenomenon of transnational mothering and left-behind children due to the prevailing feminized migration flows (Asis, 2008; Parreñas, 2001). The research on which this chapter is based investigated the role of the ever-proliferating new communication technologies for Filipino families whose members experience extended periods of separation. What makes the Philippines particularly interesting for examining the convergence of new media and migration is that the country is at the forefront of digital media developments, especially mobile phones (Madianou and Miller 2012; Pertierra, 2010). The primary aim of this chapter is not to report on the findings of this research as this has been done elsewhere (see Madianou, 2012; Madianou and Miller, 2012), but to address the deeper implications of the 
Original citation: Madianou, M. (2016) 'Polymedia communication among transnational families: what are the long-term consequences for migration?' In Palenga, E. and M. Kilkey (eds) Family Life in an Age of Migration and Mobility: Global Perspectives through the Life Course, pp. 71-93. London: Palgrave.

increasingly ubiquitous presence of new media in transnational family life. In order to do so, I will first map the processes of transnational communication and contrast the perspective of migrant mothers to that of their left-behind families. This micro perspective of family communication provides the explanatory framework for understanding the cumulative and more macro consequences of technologically mediated communication. Although new communication technologies do not solve the problems of family separation, their increasing taken-for-grantedness in Filipino social life suggests that they are becoming integral to the wider phenomenon of migration. The analysis will observe that migrants increasingly justify decisions relating to migration and settlement on the availability of transnational communication echoing an optimistic discourse about the role of communication technologies found in the Philippine public life. In order to trace the trajectory from micro to macro consequences of transnational communication the research on which this chapter is based cast a wide ethnographic lens that encompasses not just interviews with transnational families but also a broader ethnography of institutions that deal with and regulate migration in the Philippines.

\section{Migration and transnational families}

Although families whose members are separated because of migration are not a new phenomenon (Thomas and Znaniecki, 1984), they have undergone significant changes in recent years in the context of the intensification and feminisation of global migration (Hondagnau-Sotelo and Avila, 1997; Parreñas, 2001). Transnational mothering and the phenomenon of the left-behind children are usually described in the most poignant terms as the hidden injuries of globalisation, the social cost of 
Original citation: Madianou, M. (2016) 'Polymedia communication among transnational families: what are the long-term consequences for migration?' In Palenga, E. and M. Kilkey (eds) Family Life in an Age of Migration and Mobility: Global Perspectives through the Life Course, pp. 71-93. London: Palgrave.

migration which the poorer countries have to pay in exchange for the remittances that keep their economies afloat. The Philippines exemplifies this phenomenon with over 9 million overseas workers and 9 million children growing up without one or both their parents (Parreñas, 2008: 68). The dominant paradigm in the analysis of transnational mothering has been the 'care chain' approach (Parreñas, 2001). Drawing on the political economy of global care, the approach focuses on the structural relations that people form globally based on paid or unpaid care. While the approach has been significant for drawing attention to the power asymmetries in the provision of care in the context of globalisation, it has overlooked the agency of migrants (McKay, 2007). The present chapter adopts an ethnographic approach which puts the experience of migrants and their families at the heart of the analysis. The emphasis here is how members of transnational families negotiate their contradictory social positions within structures of power in order to achieve some kind of family life at a distance. The ethnographic perspective is also suitable for capturing the complex and ambivalent emotions relating to separation, reunion and family life more generally.

Parallel to the anxieties about the consequences of family separation for migrants and their children, transnational families can also exemplify recent theories of the family as 'sets of practices' (Morgan, 1996). The deterritorialised nature of transnational families necessitates a rethinking of family life departing from traditional definitions of family as a static entity which is physically co-present. Instead family can be thought of as a set of practices that can take place in a range of contexts, including mediated. In this sense family is better understood as a verb ('doing family') rather than a noun (Morgan, 1996). In the absence of physical copresence transnational family members can only 'do family' through daily actions 
Original citation: Madianou, M. (2016) 'Polymedia communication among transnational families: what are the long-term consequences for migration?' In Palenga, E. and M. Kilkey (eds) Family Life in an Age of Migration and Mobility: Global Perspectives through the Life Course, pp. 71-93. London: Palgrave.

which are typically mediated by communication technologies. Communication practices, such as making a phone call or sending a text message, become the key practices through which family comes into being. As with non-mediated practices, acts of mediated communication can have complex consequences, both positive and negative, depending on a number of factors including the relationships in question.

Given transnational families' dependency on mediated communication it is surprising that for years migration research neglected the role of communication technologies. This has changed recently with the emergence of new research which has analysed communication as integral to transnational family practices (Baldassar, 2008; Madianou, 2012; Madianou and Miller, 2012; Parreñas, 2005; Wilding, 2006). Studies have highlighted different aspects of the role of mediated communication both negative and positive - for transnational relationships such as the way they amplify gender asymmetries (Parreñas, 2005) or facilitate emotional expression (Baldassar, 2008). What requires more systematic analysis within transnational families research is the nature of communication technologies. Communication technologies are complex 'architectures' (Papacharissi, 2009) which facilitate some types of interaction and not others. Understanding the nature of different communication technologies and how these constitute larger media environments is essential for comprehending their consequences for transnational family practices.

\section{Communication technologies, affordances and polymedia}

This chapter draws on a sociotechnical approach to communication technologies in order to develop an understanding of mediated communication for transnational family relationships and migration more broadly. The proliferation of new 
Original citation: Madianou, M. (2016) 'Polymedia communication among transnational families: what are the long-term consequences for migration?' In Palenga, E. and M. Kilkey (eds) Family Life in an Age of Migration and Mobility: Global Perspectives through the Life Course, pp. 71-93. London: Palgrave.

communication technologies has given rise to new, potentially rich interactions at a distance which largely overcome some of the constraints that had been associated with earlier forms of mediated communication. New media offer a range of affordances - essentially referring to properties of design characteristics of media which enable or constrain certain types of action (boyd, 2014; Hutchby, 2001)which provide a rich canvas for personal communication. Recent research highlights the varied ways in which users employ digital media for personal communication (Baym, 2010) and supplement face-to-face interactions. Rather than undermining the quality of relationships studies have found that people with strong bonds tend to use more media, more frequently in order to sustain their relationships (Haythornthwaite, 2005). The notion of polymedia, developed in earlier research on transnational communication practices, holds that media operate as environments of affordances which users navigate in order to manage their relationships (Madianou and Miller, 2012).

Polymedia understands media as part of a composite environment within which each medium is defined relationally to all other media from the point of view of the user. In the pre-internet age, when it was common to rely heavily on a single medium in order to keep in touch (for example, letters), we saw that the particular properties of the technology or medium shaped interactions in specific ways. For instance, the time lag of letters meant that 'news' reported in a letter were always several weeks old by the time the letter was received. The temporality of letters caused frustration amongst letter-writers (Madianou and Miller, 2011). But in the present situation when users have access to dozens of different applications, platforms and devices, we observe that they begin to exploit the qualities, or affordances of each 
Original citation: Madianou, M. (2016) 'Polymedia communication among transnational families: what are the long-term consequences for migration?' In Palenga, E. and M. Kilkey (eds) Family Life in an Age of Migration and Mobility: Global Perspectives through the Life Course, pp. 71-93. London: Palgrave.

platform in order to compensate for the limitations of other platforms. A polymedia framework shifts the emphasis from discrete technologies or platforms to an appreciation of media environments. Rather than focusing on the properties, or affordances of specific technologies, polymedia shifts our attention to how users navigate media environments and choose platforms from a range of communicative opportunities. Choosing a medium among several available acquires emotional intent and becomes key to how people manage relationships (Madianou and Miller, 2013). Assuming users have unconstrained access to, and can skilfully use at least half a dozen communication media, the choice of one medium (for instance, email) over another (say, Skype) acquires communicative significance. Choosing email, which has an asynchronous structure, over other synchronous platforms (such as calling or videocalling) may express a desire for some distance in the communication context. Polymedia then allows us to observe the management of transnational relationships and the role of technological mediation in this process.

Apart from being a theory that explains the inner workings of mediated communication, polymedia is also attentive to wider questions of social change. For example, research has revealed that the pervasiveness of media environments can accentuate social phenomena and contribute to the emergence, or entrenchment of social class (Qiu, 2009) or inequality (Madianou, 2015). At this point polymedia converges with parallel theoretical approaches such as 'mediatization' which combines both how the social is captured in the media and how in turn the media have 'a contextualised consequence for the [...] social construction of reality' (Couldry and Hepp, 2013: 196). In order to capture this essentially dialectical process, the ethnography that informs this chapter followed the 'circulation of discourses' 
Original citation: Madianou, M. (2016) 'Polymedia communication among transnational families: what are the long-term consequences for migration?' In Palenga, E. and M. Kilkey (eds) Family Life in an Age of Migration and Mobility: Global Perspectives through the Life Course, pp. 71-93. London: Palgrave.

(Silverstone, 1999) and practices relating to communication technologies among transnational family members, but also institutional actors. The wide lens perspective is essential for tracing the consequences of mediated communication not just at a micro but also at a macro level.

This discussion on mediated communication assumes that migrants and their families have access and are able to use creatively a range of communication technologies. Contrary to popular stereotypes which cast migrants as perpetually destitute and information poor, recent research points out that certain groups of economic migrants (though certainly not all) are early and enthusiastic adopters of new technologies (Fortunati, Pertierra and Vincent, 2012; Hepp et al, 2012; Madianou and Miller, 2012). Migrants are often sophisticated users of new communication technologies on which they depend in order to keep in touch with families back home (Madianou and Miller, 2012), or to improve their life chances before and post migration (Elias and Lemish, 2009; Hiller and Franz, 2004). Transnational families, supported by remittances and increased status in the sending countries, are often prepared to invest in hardware and face the necessary connection costs and this was certainly the case among the Filipino families this chapter is based on.

\section{The empirical and research contexts}

With over $10 \%$ of the population working abroad and over one million migrants deployed annually (Asis, 2008) the Philippines represents one of the major sources of migrant labour. Remittances reached 24 billion USD for $2012^{1}$ making the Philippines one of the top three remittance-receiving countries globally, behind China and India, both much larger countries (Pew Research Center, 2013). The dependency of the 
Original citation: Madianou, M. (2016) 'Polymedia communication among transnational families: what are the long-term consequences for migration?' In Palenga, E. and M. Kilkey (eds) Family Life in an Age of Migration and Mobility: Global Perspectives through the Life Course, pp. 71-93. London: Palgrave.

Philippine economy on remittances explains why migration is key to the government's economic policy (Acacio, 2008; Asis, 2008) and why the state actively promotes and regulates migration. Ever since the years of the Marcos dictatorship, migrants have been celebrated as 'the heros of the Philippine economy' (Asis, 2008). The Philippine government has signed bilateral agreements with countries, especially in the Middle East, to provide them with workers usually on short-term contracts. Dedicated government agencies identify needs in the global labour market and then actively recruit, train, and deploy Filipino workers. The one million annual deployment figure quoted above was an official government target (Asis, 2008). The demand for care and domestic work in the so-called 'global north' has been one of the factors contributing to increased female migration (Parreñas, 2001). While in previous decades Philippine migration was predominantly male with emphasis on seafaring and manual labour, in recent years women are as, or more likely, than men to migrate. Given that many of these female migrants are mothers the Philippines has come to exemplify the phenomenon of transnational mothering (Hondagneu-Sotelo and Avila, 1997; Hochschild, 2000; Parreñas, 2005).

Female migration and transnational mothering have been sources of contestation within Philippine society. While the government promotes and encourages female migration many still publicly decry the family separation this often entails. It is worth noting that this debate is primarily addressed to female migration and not to male migrants who are as likely to be fathers separated from their children. This confirms the continued prevalence of traditional gender roles and stereotypes about motherhood and mothering as 'the light of the home' (Arellano-Caradang, Sisin and Caradang, 2007). Despite the Philippines' pre-existing tradition of internal 
Original citation: Madianou, M. (2016) 'Polymedia communication among transnational families: what are the long-term consequences for migration?' In Palenga, E. and M. Kilkey (eds) Family Life in an Age of Migration and Mobility: Global Perspectives through the Life Course, pp. 71-93. London: Palgrave.

migration and the strong culture of outward migration, female migration remains contested. Newspaper columnists frequently comment on the social costs of separation and 'bad mothers' who leave their children behind, while popular culture is full of stereotypes of troubled youth who grow up without maternal love and care (see Parreñas, 2008). Popular films such as $\mathrm{Anak}^{2}$ (the Tagalog word for child) portray a left-behind daughter who falls into a world of vices after her mother leaves for Hong Kong. My ongoing research with Filipina migrant women focuses on how they negotiate these contradictory discourses that simultaneously brand them 'bad mothers' and 'heros of the economy'.

The UK is one of the most popular destinations for Filipino nurses and caregivers (POEA, 2010), while conservative estimates put the UK Filipino population at 200,000. A great proportion of migrants arrived between 1999 and the mid-2000s as the UK's National Health Service systematically recruited nurses from the Philippines. ${ }^{-}$The UK Filipino population also includes domestic workers and nannies as well as caregivers who typically came to the UK on student visas and therefore do not appear in the official statistics. Recent changes in UK law have stemmed the arrival of careworkers on student visas. However, my ethnography suggests that several of those who arrived on student visas remain in the UK often without documents. ${ }^{4}$ The strong presence of Filipino migrants in the care sector suggests that the UK Filipino population is strongly female as confirmed by earlier statistics (POEA 2005). Although there are no official statistics, my long-term involvement with Filipino communities in England suggests that these migrants, often including domestic workers, tend to be college educated. There are, however, significant class and occupational divides among Filipino migrants which map onto 
Original citation: Madianou, M. (2016) 'Polymedia communication among transnational families: what are the long-term consequences for migration?' In Palenga, E. and M. Kilkey (eds) Family Life in an Age of Migration and Mobility: Global Perspectives through the Life Course, pp. 71-93. London: Palgrave.

parenting practices. Nurses, for example, are more likely to visit their families once or twice a year compared to domestic workers who visit less regularly and irregular migrants who may not visit for years. Nurses are more likely to have better online access than domestics, as are their largely urban middle-class families back in the Philippines. Still, the arrival of smartphones and cheap netbooks has opened the opportunities for transnational communication for even the least privileged of migrants within this group. Broadly speaking, many Filipino migrants in the UK (though certainly not all) come from what would be considered middle-class backgrounds confirming migration patterns to other destinations (see Constable, 1999), although the notion of middle class in the Philippines does not entail the same degree of security as in Europe or the US (Parreñas, 2001). This confirms a wider a pattern in the migration literature: a large majority of migrants already possess the necessary economic, social, and cultural capital in order to undertake the expensive project of migration (Portes and Rumbaut, 2006).

The research which informs this chapter consists of participant observation and interviews which took place in 2007 and 2010 and has continued intermittently to the time of writing (2015). ${ }^{5}$ The first period of research (2007-2008) was UK-based and consisted of 53 interviews with Filipino migrants, mainly women with children left behind. During this time we developed links with and spent time at Filipino associations and centres in London and Cambridge. This first research phase was followed by fieldwork in the Philippines during 2008/9 consisting of 53 in-depth interviews and participant observation with the (young adult) children of some of these mothers as well as other left-behind children. During this period we also met several other participants (family members, carers, and younger left-behind children) 
Original citation: Madianou, M. (2016) 'Polymedia communication among transnational families: what are the long-term consequences for migration?' In Palenga, E. and M. Kilkey (eds) Family Life in an Age of Migration and Mobility: Global Perspectives through the Life Course, pp. 71-93. London: Palgrave.

as part of the ethnographic encounter while I also interviewed representatives from government agencies and regulatory bodies dealing with migration as well as officials from migration agencies, advocacy groups, and telecommunications companies. I also attended the mandatory 'Pre-Departure Orientation Seminars' organized by the Philippine Overseas Employment Agency (POEA) for migrants prior to their deployment to the UK. On returning from the Philippines, I re-interviewed and continue to maintain contact with a dozen of the initial participants as well as their families in the Philippines. In total, 106 participants were interviewed (several of whom more than once) and we were able to pair 20 mothers and children.

This research has traced participants involved in different aspects of the migration process. The empirical section will begin with a discussion of the public and institutional discourses regarding new media in the context of migration and family separation. Such accounts reveal the wider social assumptions about the role of communication technologies in the context of family separation. I will observe the optimism regarding the arrival of new media, especially mobile phones, for alleviating the social costs of migration. This will be contrasted to the perspective of migrants as well as their left-behind children. Contrasting these perspectives allows us to observe the circulation of discourses on migration and transnational communication and to assess the consequences of mediated communication for the phenomenon of migration.

\section{The institutional perspective}

A unique feature of Filipino migration is the role of the government in actively promoting and controlling emigration. This is evident in the government-sponsored 
Original citation: Madianou, M. (2016) 'Polymedia communication among transnational families: what are the long-term consequences for migration?' In Palenga, E. and M. Kilkey (eds) Family Life in an Age of Migration and Mobility: Global Perspectives through the Life Course, pp. 71-93. London: Palgrave.

'pre-departure orientation seminars' which are a mainstay of the Filipino migration experience. These one-day workshops are mandatory for all migrants before deployment and are typically organized by the dedicated government department dealing with emigration. The Philippine Overseas Employment Administration (henceforth POEA) issues all visas and contracts and these will typically be signed off on the successful completion of a pre-departure orientation seminar. The seminars consist of practical information about the destination country as well as advice about what constitutes proper conduct and behaviour when abroad.

I attended such a workshop in the crowded and labyrinthine POEA building in Manila in January 2009. The workshop was aimed for migrants departing for Europe - including the UK - and the overwhelming majority of participants in that workshop were women who were taking up care and domestic jobs. A whole section of the workshop was dedicated to the migrants' responsibilities to the left-behind family which included the duty to keep in touch. Much of the discourse here concerned the possibilities for keeping in touch afforded by developments in mobile communication. The tone of the workshop leader was celebratory, taking technological progress for granted. As she stated: 'there's no longer any excuse not to communicate'.

'And you have a duty to your family. Who are married? Raise your hands. [Do not] forget about your family in the Philippines. [...] because your family is the reason why you're leaving the country. You're providing financial and moral support to your family in the Philippines. And you have to communicate. You have to communicate with your family as often as you can. There's no excuse not to, because we all have cell phones now. In the 
Original citation: Madianou, M. (2016) 'Polymedia communication among transnational families: what are the long-term consequences for migration?' In Palenga, E. and M. Kilkey (eds) Family Life in an Age of Migration and Mobility: Global Perspectives through the Life Course, pp. 71-93. London: Palgrave.

previous years, OFWs [Overseas Foreign Workers] didn't have cell phones. How did they communicate? They'd send letters because overseas calls were very expensive. Sometimes they'd record their voices. The families here would listen to them on radio through cassette tapes. But shipping takes a while. It takes one month, two months to send something to your loved ones. But nowadays, there's no excuse anymore. You have the cell phone. You can call your loved ones. You cannot abandon your families, okay?' Seminar leader, Pre-departure orientation seminar (PDOS), Philippine Overseas Employment Agency (POEA), Manila, January 2009

Similarly, the Overseas Workers Welfare Administration (henceforth OWWA), the other major government unit dealing with migration and especially the migrants' welfare, recognizes the importance of transnational communication and has developed a dedicated digital literacy training programme for migrants and their left-behind families. The Tulay programme (tulay meaning bridge in Tagalog) was developed in partnership with Microsoft and the Department of Labor and Employment and takes place in Community Training Learning Centres (CTLC) throughout the country as well as in international destinations with significant Filipino populations, such as Hong Kong and Riyadh. ${ }^{6}$ The officer in charge of the training programme expressed certainty about the ability of the internet and webcam in particular to keep the separated families together.

'So this is about training. It gives them a way to communicate across the distance because you see the problems of our OFWs; they are being lonely 
Original citation: Madianou, M. (2016) 'Polymedia communication among transnational families: what are the long-term consequences for migration?' In Palenga, E. and M. Kilkey (eds) Family Life in an Age of Migration and Mobility: Global Perspectives through the Life Course, pp. 71-93. London: Palgrave.

because they cannot see their loved ones. But because of the webcam, they can now see their loved ones everyday. And of course it keeps certain bonds with the family because of these internet facilities.' Tulay programme officer, Manila January 2009

This vision about the power of technology is echoed by representatives of mobile phone companies themselves which now recognize migrant families as a lucrative market. The Philippines is at the forefront of mobile phone and other digital developments (Madianou \& Miller 2012; Pertierra 2010) with over 100\% mobile teledensity (World Bank, 2012). The Philippines is popularly referred to as the texting capital of the world with over 1.4 billion SMS messages sent each day (Reuters, 2008) while more recently it is described as 'the social networking capital of the world' (Russell, 2011) with a Facebook penetration rate of $94 \%$ among internet users. Several mobile phone innovations have been launched in the Philippines such as G-Cash, a mobile phone application which allows users to send remittances bypassing banks or other traditional intermediaries. G-Cash is effectively a mobile money platform (like Kenya's M-Pesa) and was one of the first such applications to be launched globally (in 2004) precisely to meet the large demand for sending remittances to the Philippines.

Both major telecommunication companies, Globe and Smart, have dedicated departments for developing and marketing products to migrants and their families. Globe's marketing strategy for the OFW market included slogans such as: 'With Globe's Worldwide Services, the family will always be together. [Palagi buo ang pamilya.] And: 'Christmas is more colorful and happier when the family is together.' 
Original citation: Madianou, M. (2016) 'Polymedia communication among transnational families: what are the long-term consequences for migration?' In Palenga, E. and M. Kilkey (eds) Family Life in an Age of Migration and Mobility: Global Perspectives through the Life Course, pp. 71-93. London: Palgrave.

Or: 'With Globe, you're always together.' These slogans are echoed by managers in the telecommunications sector such the one who claimed in an interview: 'We keep [the OFW families] together'. Both companies have extensive advertising campaigns which dominate the national media.

Turning migrants into a market and branding migration as a source of national development as the government does is a neoliberal practice where economic gain and consumption power are given priority over other social values. New media from mobile phones to webcam - both private resources - are promoted as the solutions to social problems. The wide availability of cheap (or at least cheaper) transnational communication serves as a justification for otherwise socially contested decisions. Both state and the market seem to be in unison here in suggesting that new media can alleviate the social costs of migration. The synergy between state and telecommunications companies is evident at many levels including in sponsorships of competitions and public events which celebrate migration. Globe, for instance, sponsors OWWA's 'Model OFW Family of the Year' competition which recognizes a financially successful migrant family whose members maintain close family ties despite separation. This competition seems to encapsulate the neoliberal ideology of the government of the Philippines with its emphasis on economic gain and individualism cloaked under a veil of ethical responsibility (Ong, 2006).

Do these public discourses about technology and migration resonate with the experiences of migrants themselves and their left-behind families? Is the 'technological vision' within which interactive media are framed justified when assessing the success of transnational communication? The following sections provide answers to these questions. 
Original citation: Madianou, M. (2016) 'Polymedia communication among transnational families: what are the long-term consequences for migration?' In Palenga, E. and M. Kilkey (eds) Family Life in an Age of Migration and Mobility: Global Perspectives through the Life Course, pp. 71-93. London: Palgrave.

\section{The migrant mothers' perspective}

What was striking in many interviews is that most migrant participants embraced new communication technologies as opportunities to perform 'intensive mothering at a distance' (Madianou, 2012). The performance of intensive mothering depends largely on the age of the children. Mothers with young children found webcam invaluable as it allowed them to maintain a communication which would never have been possible on the phone as children appreciated the visual aspect of webcam. Mothers also appreciated the fact that they were able to see their children in what is a period of rapid development. The visual affordance of webcam also allowed mothers to be recognized by their children as mothers. The importance of this becomes evident once we contrast it to the period of letter writing when mothers returned to the Philippines after two or more years' abroad and their children would no longer recognize them. Many mothers experienced this disconnect as a rejection. As Sandra, a domestic worker in her 40s and mother of two put it: when her daughter failed to recognise her after she had been abroad for four years she felt like an 'incomplete mother'.

As the children grow older more media platforms are introduced. We then observe that different media are used for different purposes: Instant Messaging (IM) was popular for helping with homework, while email worked well for sending detailed instructions or explaining bills. People begin to exploit the environment of polymedia within which each platform acquires its own niche depending on its affordances and the relationships in question. Mothers spend a significant proportion of their income and time to fulfil their communication needs which they consider a top priority. Our participants know an impressive amount of detail about their children's daily lives, 
Original citation: Madianou, M. (2016) 'Polymedia communication among transnational families: what are the long-term consequences for migration?' In Palenga, E. and M. Kilkey (eds) Family Life in an Age of Migration and Mobility: Global Perspectives through the Life Course, pp. 71-93. London: Palgrave.

ranging from what the family had for dinner to the feedback on the children's latest school assignments. Apart from opportunities for intimacy and care at a distance new media also afforded opportunities for surveillance and monitoring. Mothers routinely perused social media such as Facebook, for cues on their children's social lives. The increased social cues afforded by a combination of media provide migrant women with evidence of life back home. Evidence is closely linked to control and this is an important dimension of the mothers' enthusiasm for new media. Women now feel they are much more in control over what happens in their households 'as they can see with their own eyes' whether their children are looking healthy or whether their remittances are spent in the way they had directed. Micromanaging a household at a distance can be fraught and women describe how they become involved in family conflict. Still many participants preferred being involved than being left out. As one participant put it: 'This way I can do something about [the problems'.

Many participants reported that frequent communication often amplified conflict if not with their children, then with other family members. While in the past problems were hardly ever reported in letters, in situations of frequent communication it is much harder to keep family secrets. This is not the only burden of communication: being always 'on' and available through one's smartphone means that they are also potentially available to help family members in need. Through my long term rapport with my participants it became apparent that requests for help - which were often incessant - put a great strain on them, not least financially. Additionally, frequent communication revealed its limitations on a daily basis: despite the 'ambient copresence' of family life afforded by mobile devices and wi-fi capabilities, mediated 
Original citation: Madianou, M. (2016) 'Polymedia communication among transnational families: what are the long-term consequences for migration?' In Palenga, E. and M. Kilkey (eds) Family Life in an Age of Migration and Mobility: Global Perspectives through the Life Course, pp. 71-93. London: Palgrave.

interactions still left mothers desiring the smell and touch of their children. This perhaps explains why many Skype calls end in tears.

\section{The 'left-behind' families' perspective}

If mothers were quick to embrace new communication technologies, their left-behind children were more ambivalent about the success of long-distance communication. Our sample was evenly split into two groups. One the one hand we encountered a group of young adults for whom communication technologies provided a solution to their relationships and who even reported an improvement in relationships postmigration. On the other hand, a group of our participants reported that new communication technologies did not help in their relationship with their parents. The latter group share a number of characteristics pointing to four parameters that determine the success of transnational communication. First, most of those for whom new media did not work were very young (typically under 10 years old) at the time of their mothers' migration. The second parameter is the availability of communication technologies. For our group of participants whose mothers left when they were young this was a time when communication was infrequent and expensive - letters took up to a month to arrive while phone calls were prohibitively expensive. It seems that during this time a gap was formed that was hard to fill even with the advent of new media. The remaining factors are the quality of the pre-existing relationship and the quality of transnational care arrangements.

The 'always on' culture facilitated by new communication technologies often brought to the surface problems or family disputes which had been previously concealed. The story of Reno illustrates this: at the age of 14 Reno dropped out of 
Original citation: Madianou, M. (2016) 'Polymedia communication among transnational families: what are the long-term consequences for migration?' In Palenga, E. and M. Kilkey (eds) Family Life in an Age of Migration and Mobility: Global Perspectives through the Life Course, pp. 71-93. London: Palgrave.

school. He stayed at home all day playing video games and watching television to the dismay of his elderly grandmother and 16-year-old sister who was effectively his carer. Neither the sister nor the grandmother had found the courage to tell the migrant mother who was abroad in the first place in order to raise money to pay for her children's private education. What revealed the truth to the mother was the son's status (the symbol that indicates that a user is online) on Yahoo Messanger, a popular IM platform in 2009. The mother noticed that her son's status was 'on' when he was supposed to be in school. This is an example of how technological features can 'leak' information with consequences for the personal relationships of those involved.

A clear pattern emerged among left-behind children who for years experienced infrequent communication with their parents such as the monthly letter or the weekly call. The arrival of mobile phones and internet platforms made communication frequent and spontaneous. This change was not always welcome. It was often experienced as intrusive and as a form of monitoring. It is easy to see the power shift from a time of pre-planned and ritualised communication (the Sunday phone call) to a situation when teenagers and young adults are assumed to be available and contactable throughout the day. Technological change mapped onto already asymmetrical relationships and accentuated power imbalances. Much effort was expended on how to avoid such communication often causing friction in the relationship. Ricardo, for instance, often left his mother's call to his mobile phone unanswered and replied via email instead. By switching to a platform with an asynchronous temporal structure (email) Ricardo was able to regain some control in the relationship - the kind of control he had in the period of letter writing and weekly phone calls when he know when to expect a communication and how to prepare his 
Original citation: Madianou, M. (2016) 'Polymedia communication among transnational families: what are the long-term consequences for migration?' In Palenga, E. and M. Kilkey (eds) Family Life in an Age of Migration and Mobility: Global Perspectives through the Life Course, pp. 71-93. London: Palgrave.

response. The switching of platforms is an example of communication in a polymedia environment, when users exploit the affordances of different platforms and in so doing manage their relationships.

By contrast, those for whom new media provided solutions to their relationships were older at the time of their mothers' migration (usually in their teenage years). For those older participants, their parents' migration typically took place in the years following the arrival of new media - at least mobile phones - and so communication was more frequent and affordable. These teenagers also reported a strong bond with the mother prior to her departure. The parents' migration afforded the teenagers with increased autonomy and enabled them to flourish independently. At the same time the availability of media provided them with the emotional security needed at a time of rapid changes and challenges. Cecilia, for example, developed a very close bond with her mother following her migration. Cecilia describes her mother as her 'best friend'. The two women go internet shopping together by visiting the same sites whilst on Skype and sending pictures of their clothes as attachments. When her mother developed a serious illness, Cecilia used webcam to support her emotionally. Skype calls often lasted for hours while mother and daughter shared family stories but also personal secrets regarding their personal relationships. Such conversations continued after the mother's recovery and through Cecilia's University studies. The fact that their relationship was largely freed from the routines and chores of everyday life (the mother didn't have to ask the daughter to tidy up her room, for example) transformed their relationship into a kind of 'pure relationship' (Giddens 1991) existing primarily for their mutual enjoyment. 
Original citation: Madianou, M. (2016) 'Polymedia communication among transnational families: what are the long-term consequences for migration?' In Palenga, E. and M. Kilkey (eds) Family Life in an Age of Migration and Mobility: Global Perspectives through the Life Course, pp. 71-93. London: Palgrave.

\section{The consequences for migration}

Comparing the migrant mothers' and left-behind children's perspective reveals that new media cannot solve the problems of family separation. While for some families new media constitute solutions, for others they reveal or accentuate problems which had hitherto been concealed. New media can even accentuate conflicts and appear to deteriorate relationships. This should not be taken to mean that new communication technologies have no consequence for personal relationships. What we observe is that new media become constitutive of how relationships are enacted and experienced (see also Madianou and Miller, 2013). In the absence of face-to-face contact our participants exploit the affordances of communication technologies in order to manage their relationships. Choosing one medium over another acquires emotional intent. In other words, the ways in which participants navigate the media environments they have access to becomes as meaningful for their relationships as the actual content that is exchanged through these platforms. These observations illustrate the theory of polymedia: the analysis of communication technologies as a composite environment in which the different components (media technologies) are relationally defined from a users' point of view (Madianou, 2015). Texting acquires emotional significance when chosen over a range of alternative platforms that may afford greater synchronicity, visuality or interactivity. Assuming cost issues are not overriding communication decisions - which they are increasingly not with the popularisation of smartphones, wireless services and post-paid contracts, switching between media technologies becomes expressive of emotions. In this context, polymedia practices become an integral part of 'doing family' (Morgan, 1996) in a deterritorialised setting. Apart from this constitutive role of media in the experience of family 
Original citation: Madianou, M. (2016) 'Polymedia communication among transnational families: what are the long-term consequences for migration?' In Palenga, E. and M. Kilkey (eds) Family Life in an Age of Migration and Mobility: Global Perspectives through the Life Course, pp. 71-93. London: Palgrave.

relationships there appears to be a further significant consequence for processes of migration more generally. To understand this we need to return to the mothers' perspective.

From the early stages of this research a persistent question kept coming up: why did our participants not return to the Philippines after the key economic motivations that propelled them to migrate had been dealt with? Why did they not return when their loans were repaid, or when the family house was finally built? Why did they prolong their stay in London or Cambridge given how much they missed their children? After all they often described themselves as temporary migrants, echoing the words and policies of their own government. Finding an answer to this puzzle became important as it seemed inevitably connected to the key question the research sought to answer which is about the nature of these transnational mediated relationships.

In order to answer this puzzle we need to look into participants' personal trajectories and wider migratory experience which we were able to do through the ethnography. Our ethnography did not just examine people' uses of media but also their personal histories, relationships, aspirations and how all these combined into the key decisions about migration: the motivations for migration, the reasons for returning to the Philippines or settling abroad, and the ways in which such decisions were justified. Examining the motivations for migration revealed that a convergence of factors led to the decision to migrate. Apart from the well-documented economic motivations (which ranged from situations of urgent need to aspirations of home ownership and private education for one's children) we found a plethora of social and other personal motivations including the desire for autonomy and self-respect (see 
Original citation: Madianou, M. (2016) 'Polymedia communication among transnational families: what are the long-term consequences for migration?' In Palenga, E. and M. Kilkey (eds) Family Life in an Age of Migration and Mobility: Global Perspectives through the Life Course, pp. 71-93. London: Palgrave.

Madianou, 2012). Economic reasons are almost always coupled with other personal motivations which need to be understood in the context of gender and other power relationships in the Philippines. As we argued earlier in the chapter, gender relations and the dominant patriarchal values stood out as a significant push factor for female migration. In this context it is not surprising that several participants talked about their migration as a form of empowerment despite the hardships and relationships of exploitation they encountered at work (see Madianou, 2012 for an extended discussion). Ultimately, migration afforded women with the respect and authority which they were never granted within their family contexts. As one of my participants told me: 'My family only started listening to me after I started sending remittances'. Unsurprisingly, many women were reluctant to give up their newfound status and sense of personhood once their contracts came to an end. Returning to the Philippines would almost certainly entail unemployment and a return to a situation of dependency on other relatives. So many of our participants decided to prolong their migration and continue to stay in the UK despite the fact that the most compelling economic factors that catalysed their migration had been dealt with. Although migration to the UK is considered officially to be short-term (according to the Philippine government), it appears to be gradually turning into a long-term migration or diaspora. In fact most of my participants have successfully applied for British citizenship in the past five years.

Yet it remains controversial for a mother to articulate self-respect and autonomy as reasons for prolonging the separation from one's children. As discussed earlier in the chapter female migration and family separation are still contested within the Philippines despite government policies which encourage migration. Interestingly, participants decided to justify their decisions by referring to their newfound ability to 
Original citation: Madianou, M. (2016) 'Polymedia communication among transnational families: what are the long-term consequences for migration?' In Palenga, E. and M. Kilkey (eds) Family Life in an Age of Migration and Mobility: Global Perspectives through the Life Course, pp. 71-93. London: Palgrave.

mother at a distance through new media. Nelia, a domestic worker and mother of a young boy told me: 'It's the right decision for me - as long as I keep sending money and as long as I keep calling them'. 'Calling' or practising 'intensive mothering through new media' provides women with a socially acceptable justification for their decisions which are deeper and more personal. That this justification is already in public circulation and legitimated both by the state and market (telecommunications companies) only helps to reinforce its credibility.

It is not possible to say whether it was migrants themselves or other actors such as the state or the market who first adopted the optimistic discourse about the power of media to 'keep the family together'. As is often the case, there is mutual reinforcement and not necessarily a casual relationship. Migrants appropriate new media in creative ways and leave the webcam on for hours; companies realize the market potential; governments seek to present a solution for social problems generated by flawed economic policies while in turn migrants seek justification for their personal decisions. I would not assume, however, that migrant women are simply influenced by the neoliberal ideologies of the Philippine government (Padios, 2011). The predicament of female migrants is incredibly complex as they have to negotiate not only neoliberal ideologies and conditions of labour exploitation, but also asymmetrical gender power relationships exacerbated by normative expectations of motherhood (Madianou, 2012). Many participants experienced violence or humiliation in their personal relationships and these experiences were important catalysts for migration. It is not surprising then that for these women migration can be a source of empowerment and reinvention despite the associated hardships and exploitation. Branded simultaneously as 'heroes of the economy' and 'exploited 
Original citation: Madianou, M. (2016) 'Polymedia communication among transnational families: what are the long-term consequences for migration?' In Palenga, E. and M. Kilkey (eds) Family Life in an Age of Migration and Mobility: Global Perspectives through the Life Course, pp. 71-93. London: Palgrave.

workers'; 'bad mothers' and 'light of the home'; 'breadwinners' and 'caregivers' I argue it's more important to listen to the voices of the women themselves and how they negotiate these contradictory positions.

\section{Conclusion}

This chapter has mapped the micro-dynamics of transnational family communication in polymedia environments and traced their consequences for macro processes such as decisions about migration and settlement abroad. What emerged from the analysis is that the taken-for-grantedness of personal communication at a distance is beginning to contribute to the shaping of the wider phenomenon of migration itself. Migrant women justify decisions relating to migration as well as decisions relating to the prolongation of their stay on the availability of transnational communication. Even though new media will not solve problems that are fundamentally social, the fact that they are perceived as solutions to the problems of separation reveals their significant power to contribute to the shaping of the phenomenon of migration. The availability of cheap and instant communication is not the reason why women migrate or why they prolong their stay - there are strong personal and social reasons why they choose to do so. But the availability of transnational communication makes these decisions socially acceptable. The fact that institutions dealing with migration have adopted discourses that highlight the taken-for-grantedness of new media further entrenches these views. As a result we see that new media and migration become enmeshed as is evident in lowering thresholds for migrating or settling in the UK and thus changing migration patterns. New media are more than channels for communication as they contribute to the transformation of migration as a phenomenon. 
Original citation: Madianou, M. (2016) 'Polymedia communication among transnational families: what are the long-term consequences for migration?' In Palenga, E. and M. Kilkey (eds) Family Life in an Age of Migration and Mobility: Global Perspectives through the Life Course, pp. 71-93. London: Palgrave.

Although media are more than channels for communication, they are clearly also sustaining personal communication. The structural changes are made possible through the micro-processes of mediated interactions which were analysed here as practices of 'polymedia'. It is the daily, constant and increasingly taken for granted mediated everyday communication which contributes to the patterns of migration and wider social change.

\section{References}

Acacio, K. (2008) Managing labor migration: Philippine state policy and intenational migration flows, 1969-2000. Asian and Pacific Migration Journal 17: 103-132. Arellano-Caradang, M. L., B. A. Sison and C. Caradang (2007) Nawala Ang Ilaw Ng Tahanan, case studies of families left behind by OFW mothers. Manila: Anvil. Asis, M. M. B.(2008) The Philippines. Asian and Pacific Migration Journal 17(3-4): $349-378$.

Baldassar, L. (2008) Missing kin and longing to be together: Emotions and the construction of co-presence in transnational relationships. Journal of Intercultural Studies 29(3): 247-266.

Baym, N. (2010) Personal Connections in the Digital Age. Cambridge: Polity. boyd, d. (2014) It's complicated: the social lives of networked teens. New Haven: Yale University Press.

Castles, S. and M. Miller (2009) The Age of Migration. London: Palgrave.

Constable, N. (2009) At home but not at home: Filipina narratives of ambivalent returns. Cultural Anthropology 14(2): 203-228. 
Original citation: Madianou, M. (2016) 'Polymedia communication among transnational families: what are the long-term consequences for migration?' In Palenga, E. and M. Kilkey (eds) Family Life in an Age of Migration and Mobility: Global Perspectives through the Life Course, pp. 71-93. London: Palgrave.

Couldry, N. and A. Hepp (2013) Conceptualizing mediatization: Contexts, traditions, arguments. Communication Theory 23(3): 191-202.

Elias, N. and Lemish, D. (2009) 'Spinning the web of identity: the roles of the internet in the lives of immigrant adolescents'. New Media and Society. Vol. 11, No. 4, 533 551

Giddens, A. (1991) Modernity and Self-Identity. Cambridge: Polity

Fortunati, L., R. Pertierra and J. Vincent (eds.) (2012) Migrations, Diaspora and Information Technology in Global Societies. London: Routledge.

Haythornthwaite, C. (2005) Social networks and internet connectivity effects. Information, Communication \& Society, 8 (2): 125-147

Hepp, A., Bozdag, C. and Suna, L. (2012) Mediatized Migrants. In Fortunati, L., R. Pertierra and J. Vincent (eds.) Migrations, Diaspora and Information Technology in Global Societies. London: Routledge.

Hiller, H. and T. Franz (2004) New ties, old ties and lost ties: the use of the internet in diaspora. New Media and Society 6(6): 731-752.

Hochschild, A. (2000) Global care chains and emotional surplus value. In: Will Hutton and A. Giddens (eds.), On The Edge: Living with Global Capitalism. London: Jonathan Cape.

Hondagneu- Sotelo, P. and E. Avila (1997) "I'm here, but I'm there": The meanings of Latina transnational motherhood. Gender and Society 11(5): 538-571.

Hutchby, I. (2001) Technologies, texts and affordances. Sociology 35: 441-456.

Madianou, M. (2012) 'Migration and the accentuated ambivalence of motherhood: the role of ICTs in Filipino Transnational Families'. Global Networks 12(3): 277-295. 
Original citation: Madianou, M. (2016) 'Polymedia communication among transnational families: what are the long-term consequences for migration?' In Palenga, E. and M. Kilkey (eds) Family Life in an Age of Migration and Mobility: Global Perspectives through the Life Course, pp. 71-93. London: Palgrave.

Madianou, M. (2014) 'Smartphones as polymedia', Journal of Computer-Mediated Communication, 19 (3): 667-680.

Madianou, M. (2015) 'Polymedia and ethnography: understanding the social in social media'. Social Media and Society. 1 (1-3).

Madianou, M. (2015) Digital inequality and second-order disasters. Social Media and Society. 1 (4).

Madianou, M. (in press) Ambient co-presence: transnational family practices in polymedia environments. Global Networks.

Madianou, M. and D. Miller (2012) Migration and New Media: Transnational Families and Polymedia. London: Routledge.

Madianou, M. and D. Miller (2013) Polymedia: towards a new theory of digital media in interpersonal communication. International Journal of Cultural Studies 16(2): 169187.

McKay, D. (2007) 'Sending Dollars Shows Feeling': Emotions and Economies in Filipino Migration. Mobilities 2(2): 175-194.

Morgan, D. H. J. (1996) Family Connections. Cambridge: Polity.

Ong, A. (2006) Neoliberalism as Exception: Mutations in Citizenship and

Sovereignty. Durham, NC: Duke University Press.

Padios, J. M. (2011) Dial C for Culture: telecommunications, gender and the Filipino transnational gender market. In: R. Hegde (ed), Circuits of Visibility, 212-230. New York: New York Press.

Papacharissi, Z. (2009) 'The virtual geographies of social networks: a comparative analysis of Facebook, LinkedIn and ASmallWorld', New Media and Society, 11(1 \& 2), pp. 199-220. 
Original citation: Madianou, M. (2016) 'Polymedia communication among transnational families: what are the long-term consequences for migration?' In Palenga, E. and M. Kilkey (eds) Family Life in an Age of Migration and Mobility: Global Perspectives through the Life Course, pp. 71-93. London: Palgrave.

Parreñas, R. (2001) Servants of Globalization. Women, Migration and Domestic Work. Stanford: Stanford University Press.

Parreñas, R. (2005) Children of Global Migration. Stanford: Stanford University Press.

Parreñas, R. (2008) The Force of Domesticity. New York: New York Press.

Pertierra, R. (2010) The Anthropology of New Media in the Philippines. Manila: Ateneo de Manila University Press.

Pew Research Center (2013) Changing Patterns of Global Migration and Remittances. Washington, DC: Pew Research Center.

http://www.pewsocialtrends.org/2013/12/17/changing-patterns-of-global-migrationand-remittances/ Last accessed: 13 July 2015

POEA (2005) Overseas Employment Statistics. Manila: POEA

POEA (2010) 2010 Overseas Employment Statistics.

http://poea.gov.ph/stats/2010_Stats.pdf Last accessed: 13 July 2015

Portes, A. and R. G. Rumbaut, (2006) Immigrant America, a portrait, 3rd ed.

Berkeley: University of California Press.

Qiu, J. (2009). Working-Class Network Society. Cambridge, Mass: MIT Press

Reuters (2008) http://www.reuters.com/article/idUS94568+09-Jan-

2008+PRN20080109 Last consulted: 22 November 2012

Russell, J. (2011). Philippines Named Social Networking Capital of the World. Asian

Correspondent. Available URL: http://asiancorrespondent.com/54475/philippinesnamed-the-social-networking-capital-of-the-world-indonesia-malaysia-amongst-top-

10/ Last accessed: 13 July 2015

Silverstone, R. (1999) Why Study the Media. London: Sage. 
Original citation: Madianou, M. (2016) 'Polymedia communication among transnational families: what are the long-term consequences for migration?' In Palenga, E. and M. Kilkey (eds) Family Life in an Age of Migration and Mobility: Global Perspectives through the Life Course, pp. 71-93. London: Palgrave.

Thomas, W. I. and F. Znaniecki (1984) The Polish peasant in Europe and America: a classic work in immigration history, edited and abridged by E. Zaretsky, Urbana: University of Illinois Press.

Wilding, R. (2006) “"Virtual” intimacies? Families communicating across transnational contexts', Global Networks, 6 (2): 125-42.

World Bank (2012). Information and Communications for Development: Maximizing Mobile.

http://siteresources.worldbank.org/EXTINFORMATIONANDCOMMUNICATIONA NDTECHNOLOGIES/Resources/IC4D-2012-Report.pdf Last accessed July 2015.

\footnotetext{
${ }^{1}$ http://theguardian.com/global-development/2013/jan/30/migrants-billions-overshadow-aid 2 Anak was a very popular Filipino film released in 2000 and directed by R. Quintos featuring the local film star Vilma Santos.

${ }^{3}$ Although the NHS stopped recruiting from the Philippines in the mid-2000s, recruitment has started again in 2014/15 by specific Trusts such as Cambridge University Hospitals which covers the area where my fieldwork took place http://www.cuh.org.uk/news/nursing-recruitment-workforce-workingfor-us-human-resources/cuh-welcomes-100-nurses-successful-recruitment-drive

${ }^{4}$ There are no official statistics on undocumented migrants or 'student' visa workers.

${ }^{5}$ Fieldwork in the early stages of the research (2007-8), was conducted jointly with Daniel Miller. I would like to acknowledge the support of the ESRC in funding the study 'Migration, ICTs and the Transformation of Transnational Family Life' (RES-000-22-2266).

${ }^{6}$ Community Training Centres are maintained and operated by OWWA and DOLE in all national regions. The overseas branches are administered by OWWA through the relevant Philippine Consulates.
} 